Full-text Avaijable Online at www.bioline.org.br/ja
J. Appl. Sci. Environ. Mgt. June, 2006

Vol. 10 (2) $43-47$

\title{
The Chemical Composition of Selected Indigenous Fruits of Botswana
}

\author{
*AMARTEIFIO, J O; MOSASE, M O \\ Department of Basic Sciences, Botswana College of Agriculture, P/Bag 0027, Gaborone, Botswana. E-mail: jamartei@bca.bw
}

\begin{abstract}
In the rural areas of most African countries, many people may not have access to exotic fruits and may be eating mainly indigenous fruits. Very little information is documented on the composition of these fruits. This study was undertaken to provide this information. The edible portions of four indigenous fruits (Adansonia digitata, Sclerocarya birrea, Strychnos spinosa and Vangueria infausta) were analysed for proximate composition, minerals, and selected properties using Association of Official Analytical Chemists(AOAC) methods. The values (\%) obtained were: dry matter 11.6 (S. birrea) - 86.0 (A. digitata), ash 3.9 (V. infausta)- 4.9 (S. birrea), crude protein 1.3 (A. digitata)- 3.7 (S. birrea), ADF 6.1 (S.spinosa) -39.5 (V. infausta), ADL 4.4 (S. spinosa)- 35.5 (V. infausta), NDF 6.2 (S. spinosa)- 39.4 V. infausta), pH 3.06 (A. digitata) - 3.98 ( S. birrea ), acidity 0.77 (S. spinosa) - 7.85 (A. digitata). The vitamin $\mathrm{C}$ content in $\mathrm{mg} / 100 \mathrm{~g}$ fresh sample were: 67.7 (V. infausta)- 141.3 (A. digitata). For the minerals the values (mg/100 g) were: Ca 56 (S. spinosa) - 128 (A. digitata), Mg 49 (S. spinosa) - 158 (S. birrea), $\mathrm{P}$ 50 (A. digitata)- 128 (V. infausta), K 1370 (S.spinosa) - 2183 (S. birrea), Na 13.0 (S. birrea)-21.7 (S. spinosa), Fe 0.07 (S. birrea) -0.11 (S. spinosa) and Zn 0.02 (V. infausta) - 0.22 (S. spinosa). The fruits appear to be good sources of vitamin $\mathrm{C}$, and the minerals, $\mathrm{K}$ and $\mathrm{Mg}$. They can contribute towards providing nutrient requirements particularly in the rural areas, therefore the consumption should be encouraged. @JASEM
\end{abstract}

\section{INTRODUCTION}

In Botswana there is a variety of indigenous fruits. They are valuable sources of vitamins and minerals in the rural areas where exotic species are limited. In some communities the fruits provide some of the nutrient requirements. These fruit trees are found wild and a few are domesticated. The Veld Product Research and Development undertook a project in 1997-2001 that involved the domestication and improvement of some of these wild fruit trees. Four of these fruits were analysed in this study. They are Adansonia digitata Linn, Sclerocarya birrea (A. Rich.) Hochst, Strychnos spinosa Lam and Vangueria infausta Burch .

Adansonia digitata is commonly called baobab (mowana in Setswana). It is usually harvested in April and May and it has a white pulp inside a hard husk. The pulp is edible, it has a sweet taste and makes a refreshing drink with water (Odetokun, 1996). Sclerocarya birrea, marula in English and morula in Setswana is the size of a small plum and pale yellow when ripe. The edible flesh is used to prepare juice, jam and alcoholic drinks. The fruits have considerable commercial value (Leakey, 1999). Strychnos spinosa is known as spiny monkey orange in English; and morutla in Setswana. The flesh is sweet when ripe. It has a yellowish skin but the flesh is brownish, it smells like ripened apples. Vangueria infausta is called wild medlar in English and mmilo in Setswana. The flesh is sweet and it tastes like wild apple. The fruits are brown-orange when ripe and have an orange flesh. The fresh fruit can be dried in the sun and then stored for about a year. This fruit is in season January to May and it has a potential for commercial use (Leger, 2002).

Most of the indigenous fruits are edible and they play an important role in the diet particularly in the rural areas. Information on the chemical composition of these fruits is limited. This study was therefore undertaken to obtain some of this data. This paper gives the dry matter, ash, crude protein, acid detergent fibre (ADF), acid detergent lignin (ADL), neutral detergent fibre (NDF), vitamin $\mathrm{C}$, mineral (Ca, Mg, $\mathrm{P}$, $\mathrm{K}, \mathrm{Na}, \mathrm{Fe}$, and $\mathrm{Zn}$ ) contents, $\mathrm{pH}$ and acidity of four indigenous fruits.

\section{MATERIALS AND METHODS}

Ripe fruits were collected from Veld products Research and Development in Gabane about $15 \mathrm{~km}$ from the capital, Gaborone. The fruits were sorted and the mature and unblemished ones were selected. The fruits collected were: Adansonia digitata, Sclerocarya berria, Strychnos spinosa and Vangueria infausta. The fruits were washed and the pulp of each variety was separated from the endocarp using a sterile knife. For $V$. infausta the exocarp and mesocarp were used. The edible portion of each fruit was homogenized using a blender and the mixture was then used immediately for the determination of dry matter, acidity, vitamin $\mathrm{C}$ and $\mathrm{pH}$. The homogenized mixture was dried at $100^{\circ} \mathrm{C}$ to constant weight and stored at $4^{\circ} \mathrm{C}$ in the refrigerator. These were used for the determination of ash, crude protein, $\mathrm{ADF}, \mathrm{ADL}, \mathrm{NDF}$ and the minerals (Ca, $\mathrm{Mg}, \mathrm{P}, \mathrm{K}, \mathrm{Na}$ Fe and $\mathrm{Zn}$ ).

Dry matter, ash content, crude protein, ADF, ADL, NDF, were determined using AOAC 1996 methods. Titrable acidity was determined (AOAC, 1996) by titrating $2.0 \mathrm{~g}$ fresh samples in $100.0 \mathrm{~mL}$ of water with $0.1 \mathrm{M} \mathrm{NaOH}$ using phenolphthalein as the indicator and was calculated as percentage citric acid. The $\mathrm{pH}$ was estimated (using a GLP $21 \mathrm{pH}$ meter) at $25^{\circ} \mathrm{C}$.

Ascorbic acid was estimated using the method described by Kirk and Sawyer (1991). The Kjeldahl 
method was used to analyse protein. Nitrogen was converted to crude protein using 6.25 factor. Digested samples used for the protein determination were used for the estimation of the minerals. The minerals determined were: $\mathrm{Ca}, \mathrm{Mg}, \mathrm{P}, \mathrm{K}, \mathrm{Na}, \mathrm{Fe}$ and $\mathrm{Zn}$. Ca, Mg, Fe and Zn were measured using a GBC 908 Atomic Absorption spectrophotometer. P was determined colourimetrically by the ammonium molybdate method using a Shimadzu ultraviolet Visible spectrophotometer 1601 PC. K and Na were analysed using a Corning 410 flame photometer. For the ash content the samples (2.0 g) were heated in pre weighed crucibles in a muffle furnace (Labcon, Type RM7) for two hours at $600^{\circ} \mathrm{C}$. ADF, ADL and NDF were determined using an ANKROM 200/220 fibre analyzer. All the analyses were carried out in triplicate and the mean calculated. The data was analysed using Analysis of Variance (ANOVA). Duncan's Multiple Range Test was used to compare mean values. Significance was accepted at $\mathrm{p} \leq 0.05$ level.

\section{RESULTS AND DISCUSSION}

Table one gives the details of the composition of the fruits. The dry matter content (\%) varied from 11.6 for S.birrea to 86.0 in A.digitata. The pulp of A.digitata is less juicy than that of S.birrea. For A.digitata the value obtained in this study is in agreement with the $84 \%$ and $86.8 \%$ reported by FAO (1968) and Saka et al. (1992) respectively. However it is lower than the 95.3 cited by Murray et al. (2001). The dry matter for S.birrea, S.spinosa and V.infausta is lower than the $26 \%, 53 \%$ and $26 \%$ obtained by Mateke (2001) for samples grown in Botswana. For $S$. spinosa and $V$. infausta our values are similar to the $22.1 \%$ and $26.5 \%$ respectively reported by Saka et al. (1992) for samples from Malawi. The dry matter content of S.spinosa and $V$. infausta were similar but significantly different from that of A.. digitata and $S$. birrea.

Table 1. Composition (\%) and $\mathrm{pH}\left(25^{\circ} \mathrm{C}\right)$ of the fruits analysed.

\begin{tabular}{|c|c|c|c|c|c|c|c|c|c|}
\hline \multirow[t]{2}{*}{ Fruit } & \multicolumn{9}{|c|}{ Component } \\
\hline & D M & Ash & C.P & $\mathrm{ADF}$ & $\mathrm{ADL}$ & NDF & $\mathrm{pH}$ & Acidity & Vit C \\
\hline A.digitata & $86.0 \mathrm{a}$ & $4.6 \mathrm{a}$ & $1.3 \mathrm{~d}$ & $16.2 \mathrm{~b}$ & $11.3 \mathrm{c}$ & $13.1 \mathrm{c}$ & $3.06 \mathrm{c}$ & $7.85 \mathrm{a}$ & $141.3 \mathrm{a}$ \\
\hline S.birrea & $11.6 \mathrm{c}$ & $4.9 \mathrm{a}$ & 3.7 a & $16.3 \mathrm{~b}$ & $13.7 \mathrm{~b}$ & $16.1 \mathrm{~b}$ & $3.98 \mathrm{a}$ & $0.88 \mathrm{c}$ & $128.3 \mathrm{~b}$ \\
\hline S.spinosa & $19.7 \mathrm{~b}$ & $4.6 \mathrm{a}$ & $3.3 \mathrm{~b}$ & $6.1 \mathrm{c}$ & $4.4 \mathrm{~d}$ & $6.2 \mathrm{~d}$ & $3.96 \mathrm{a}$ & $0.77 \mathrm{c}$ & $88.0 \mathrm{c}$ \\
\hline V.infausta & $23.5 \mathrm{~b}$ & $3.9 \mathrm{~b}$ & $3.0 \mathrm{c}$ & $39.5 \mathrm{a}$ & 35.5 a & $39.4 \mathrm{a}$ & $3.38 \mathrm{~b}$ & $1.71 \mathrm{~b}$ & $67.7 \mathrm{~d}$ \\
\hline MSE & 2.69 & 0.20 & 0.16 & 0.89 & 0.52 & 0.63 & 0.01 & 0.158 & 2.00 \\
\hline
\end{tabular}

D.M -dry matter, ADL -Acid detergent lignin, C.P -crude protein, ADF -Acid detergent fibre, NDF- neutral detergent fibre, MSE- Mean standard error. For each constituent, means with the same letters were not significantly different $(p>0.05)$.

The latter had the highest ash content (4.9\%) and $V$. infausta the lowest (3.9\%). The contents for A.digitata, S. birrea and S. spinosa were similar (p>0.05). The values obtained for A. digitata, $S$. spinosa and $V$. infausta are similar to the 5.0, 4.1, 3.4 respectively reported by Saka et al. (1994). For $A$. digitata the $1.98 \%$ reported by Odetokun (1996) for Nigerian species is lower than the 4.6 found in this study. However this value is similar to the $4.3 \%$ reported by FAO (1968). The $4.9 \%$ found in this study for $S$. birrea is slightly lower than the 6.8 estimated by Murray et al. (200l) for wild samples from Tanzania.

The protein content (\%) ranged from 1.3 for $A$ digitata to 3.7 for S.birrea. The protein content was low, this is in accordance with the observation of Saka et al. (1994) that the protein contents of most fruits is less than 5\%. For A.digitata the 1.3 assessed in this study is slightly lower than the 3.1, 2.5 and $2.2 \%$ reported by Saka et al. ( 1994), Murray et al. (2001) and FAO (1968) respectively. For S. birrea the value obtained is lower than 8.0 reported by Mateke (2001). However it is similar to the 3.6 reported by Murray et al. (20012). Also, for $S$. spinosa the $3.3 \%$ assessed in this study is lower than the 5.4 and 5.05 reported by Saka et al. (1994) and Mateke (2001) respectively. The concentration for $V$. infausta is similar to the 3.0 recorded by Mateka (2001) but lower than the 5.7 cited by Saka et al. (1994). Statistically the protein content of the fruits analysed weree significantly different. 
Table 2. Mineral contents of the fruits analysed

\begin{tabular}{lccccccc}
\hline Fruit & Mineral & \multicolumn{2}{c}{$(\mathrm{mg} / 100 \mathrm{~g})$} & & \\
\hline & $\mathrm{Ca}$ & $\mathrm{K}$ & $\mathrm{Mg}$ & $\mathrm{Na}$ & $\mathrm{P}$ & $\mathrm{Fe}$ & $\mathrm{Zn}$ \\
A.digitata & $128 \mathrm{a}$ & $1866 \mathrm{~b}$ & $121 \mathrm{~b}$ & $13.3 \mathrm{~b}$ & $50 \mathrm{c}$ & $0.10 \mathrm{ab}$ & $0.14 \mathrm{~b}$ \\
S.birrea & $94 \mathrm{~b}$ & $2183 \mathrm{a}$ & $158 \mathrm{a}$ & $13.0 \mathrm{~b}$ & $69 \mathrm{~b}$ & $0.07 \mathrm{c}$ & $0.13 \mathrm{~b}$ \\
S.spinosa & $56 \mathrm{c}$ & $1370 \mathrm{~d}$ & $49 \mathrm{~d}$ & $21.7 \mathrm{a}$ & $66 \mathrm{~b}$ & $0.11 \mathrm{a}$ & $0.22 \mathrm{a}$ \\
& & & & & & & \\
V. infausta & $124 \mathrm{a}$ & $1683 \mathrm{c}$ & $99 \mathrm{c}$ & $13.7 \mathrm{~b}$ & $128 \mathrm{a}$ & $0.09 \mathrm{~b}$ & $0.02 \mathrm{c}$ \\
MSE & 5.7 & 75 & 5.8 & 1.32 & 4.3 & 0.01 & 0.016 \\
\hline
\end{tabular}

MSE: mean standard error. For each mineral, means with the same letters were not significantly different $(\mathrm{p}>0.05)$

The highest ADF, ADL and NDF were obtained in $V$. infausta and these values were significantly different from those obtained for the other fruits . The lowest levels for ADF, ADL and NDF were obtained in $S$. spinosa. These were also significantly different from those of the other fruits. The data indicate that $V$. infausta is an important source of fibre and could be utilized if a high fibre fruit is required. There were no literature values available for comparison.

The ascorbic acid concentrations varied from 67.7 ( $\mathrm{V}$. infausta) to 141.3 (A.digitata) $\mathrm{mg} / 100 \mathrm{~g}$ on a fresh weight basis. The pulp in A. digitata is rich in ascorbic acid. The value for A.digitata is lower than the $337 \mathrm{mg} / 100 \mathrm{~g}$ and $270 \mathrm{mg} / 100 \mathrm{~g}$ cited by Eromosele et al. (1991) and FAO (1968) respectively. The ascorbic acid contents for S.birrea, S.spionsa and $V$. infausta are in agreement with the 127, 89, 68 respectively determined for samples from Botswana, Mateke (2001). Eromosele et al. (1991) obtained a higher value $403 \mathrm{mg} / 100 \mathrm{~g}$ for S.birrea. Saka et al. (1992) reported lower values 19.9 and 16.8 for S.spinosa and V.infausta respectively. The levels of ascorbic acid depend on stage of maturity and ripeness of fruit (Eromosele et al. 1991). When compared with vitamin $C$ levels of exotic and domesticated fruits such as apples (5mg/100g), oranges (50) and melon 50 (Kirk and Sawyer,1991), the fruits analysed are a rich source of this vitamin. $A$. digitata and $S$. birrea can contribute substantial amounts of ascorbic acid towards the dietary needs of the consumer. Vitamin $\mathrm{C}$ an anti-oxidant can reduce the incidence of diseases such as cancer. The ascorbic acid content for each fruit was significantly different $(\mathrm{p}<0.05)$.

The $\mathrm{pH}$ of aqueous extracts show that the edible portions of the fruits are acidic. The most acidic was A.Digitata. This may be responsible for the sour taste of the pulp. The $\mathrm{pH}$ value for the pulp of A.digitata , and $S$. spinosa are similar to the 3.30 and 4.01 respectively obtained by Saka et al. (1992). The V.infausta analysed by Saka et al. (1992) is more acidic, $\mathrm{pH} 2.18$ than the samples of the same species analysed in this study. The $\mathrm{pH}$ value for A.digitata was significantly different from those of the other fruits.

A. digitata had the highest concentration of titrable acid and S. spinosa the lowest. The high level is consistent with the low $\mathrm{pH}$ and high ascorbic acid content in A.digitata. The level in A.digitata is significantly different from that of the other fruits analysed. That for S.birrea and S. spinosa are similar. The edible portions of these two fruits are not as acidic as the pulp of A.digitata

Nutritionally these fruits could contribute positively to the mineral intake, which is evident from the results presented in table 2 . For the minerals, $\mathrm{K}$ was the most abundant element followed by $\mathrm{Mg}$ and $\mathrm{Ca}$ respectively. The levels of Fe and $\mathrm{Zn}$ were relatively low. The levels of $\mathrm{K}$ ranged from 1370 for S.spinosa to 2183 in S.birrea. The concentrations for S.spinosa, $V$. infausta and $A$. digitata are in line with the 1968.3, 1820.8 and $2836.4 \mathrm{mg} / 100 \mathrm{~g}$ reported by Saka et al. (1994). The K contents of the indigenous fruits is high in comparison with values (mg/100 g) reported for other fruits such as oranges 150, banana 400 and grapes 210 ( Holland et al. 1997).

The highest Ca level (128) was recorded for $A$. digitata while S.spinosa gave the lowest (56). The level for A.digitata is closely related to the 115.6 obtained by Saka et al. (1994) but lower than the 481 obtained by Glew et al. (1997) for samples from Burkina Faso. Also, it is more than the 60.0 cited by Eromosele (1991). These researchers reported lower Ca values for S.birrea (36.2). Our values for S.spionsa and $V$. infausta are more than the 14.9 and 13.2 respectively recorded by Saka et al. (1994). Statistically the $\mathrm{Ca}$ values for V.infausta and A.digitata were similar. The four fruits anaysed have more Ca than banana, Musa paradisiaca (7.0), ripe pawpaw, Carica papaya (15.80), mango, Mangifera india (14.0) and sweet orange, Citrus sinensis (33), Ihekoronye and Ngoddy (1985). The fruits analysed can serve as a good source of Ca. 
The Mg values ranged from 49 (S.spionsa) to 158 (S.birrea). The concentrations for A. digitata and S.spinosa are closely related to the 209 and 43 respectively reported by Saka et al. (1994). The data obtained for S.birrea is in agreement with the 140.9 reported by Smith et al. (1996) for species from West Africa. Eromoselo et al. (1991) recorded a lower value of 31.9. Also, Saka et al. (1994) cited a value of 181 for $V$. infausta, this is more than the figure obtained in this study. For each fruit the Mg value was significantly different. These indigenous fruits are a good source of $\mathrm{Mg}$ compared to the value recorded for grapes (7) and oranges (10) (Holland et al. 1997).

With Na the values obtained ranged from 13.0 for S.birrea to 21.7 for S.spinosa. The results obtained for A.digitata and S.spinosa compare favourably to the 25.3 and 18.8 reported by Glew et al. and Saka et al. (1994) respectively. The Na content of S.birrea is more than the 1.52 obtained by Glew et al. (1997). For $V$. infausta our value was lower than the 24.3 recorded by Saka et al. (1994). The Na contents of A.digitata, S.birrea and V.infausta were similar but different from that of S.spinosa. Banana and oranges have lower Na contents, 1 and 3 respectively, (Kirk and Sawyer, 1991).

The $\mathrm{P}$ concentrations obtained ranged from 50 in A.digitata to 128 for V.infausta. The 118 for A. digitata reported by FAO (1968) is more than the value obtained in this study. Our value is similar to the 45 obtained by Saka et al. (1994). Samples from Nigeria have a P content of 5.0, Ermosele et al. (1991). For S. birrea the value obtained in this study is more than 18 reported by Ermosele et al. (1991) but less than the 264 obtained by Glew et al. (1997) for samples in Bukina Faso. The 108 reported by Saka et al. (1994) for S.spinosa is more than the value obtained in this study. However for V.infausta our value is more than the 82.3 obtained by Saka et al. (1994). The P contents for S. birrea and S.spinosa were similar but significantly different from those of the other fruits. The $\mathrm{P}$ content of these fruits is more than that of banana (40), sweet orange (23) and ripe paw paw (7.4), Ihekoronye and Ngoddy (1985).

The $\mathrm{Fe}$ composition of the fruits analysed ranged from 0.07 in S.birrea to 0.11 in S. spinosa. The Fe content of A.digitata is similar to that of S.spinosa and $V$ infausta respectively but significantly different from S.birrea. The Fe value for A.digitata is similar to the 1.7 and 1.2 reported by Glew et al. (1997) and Smith et al( 1996) respectively but lower then the 5.8 and 7.4 cited by Saka et al. (1994) and FAO (1968) respectively. The Fe contents for S.birrea is lower that the 2.49 cited by Glew et al. (1997). Also lower concentrations were determined in this study compared to the. 13.6 and 28.3 respectively reported by Saka et al. (1994) for S.spinosa and V. infausta respectively. The Fe contents in these fruits are lower than those for banana (0.93), ripe paw paw (0.40) and sweet orange (0.40), Ihekoronye and Ngoddy (1985). These fruits will have to be supplemented with fruits of higher $\mathrm{Fe}$ contents in order to meet $\mathrm{Fe}$ requirements amongst consumers.

The $\mathrm{Zn}$ values were from 0.02 for $V$. infausta to 0.22 for $S$. spinosa. The data obtained for A.digitata and $S$. birrea were similar but different from that of the other fruits. For A. digitata the values obtained in this study are similar to the 1.04 and 0.64 reported by Glew et al. (1997) and Odetokun (1996) respectively. For S.birrea our value is comparable to the 0.66 obtained by Smith et al. (1996) but slightly more than the 0.34 obtained by Eromosele et al.(1991). For S.spinosa and $V$. infausta there were no data available for comparison. With the exception of $V$. infausta, the $\mathrm{Zn}$ values of the fruits analysed compare favourable with those of oranges 0.1 , banana 0.2 and grapes 0.1 (Holland et al. 1997). The values obtained in this study compared with other studies may be due to the different environment and methods of analysis.

Conclusion: The data indicate that the best source of: ascorbic acid and $\mathrm{Ca}$ is A.digitata; $\mathrm{K}$ and $\mathrm{Mg}$ is S.birrea; Fe and $\mathrm{Zn}$ is S.spinosa and $\mathrm{P}$ and fibre $V$. infausta. The study revealed that the fruits are good sources of $\mathrm{K}$ and $\mathrm{Mg}$ compared to existing domesticated fruits. Also, the vitamin C,Ca and P contents compare favourably with those of well established exotic fruits. The consumption of these fruits may help to overcome micronutrient deficiency that are prevalent in poor urban and rural areas.

Acknowledgement: We are grateful to Veld Product Research Institute for providing the samples and to Mr G Nthoiwa for analyzing the data. Also, we would like to thank the Botswana College of Agriculture for providing the funds.

\section{REFERENCES}

AOAC, (1996). Official methods of analysis. $16^{\text {th }}$ edn. Washington DC. Association of Official Analytical Chemists.

Eromosele, I C; Eromosele, C.O and Kuzhkuzha M (1991). Evaluation of mineral elements and ascorbic acid contents in fruits of some wild plants. Plant foods for human nutrition 41:151-154.

FAO, (1968). Food composition table for use in Africa. Food and Agricultural Organisation (FAO) of the United nations : Rome. http://www.fao.org/docrep/003/X6877E/X6877 E13.htm.

Glew, R.H; VanderJagt D.J, Lockett C, Grivetti L.E, Smith G.C, Pastuszyn A and Millson M 
(1997). Amino acid, fatty acid and mineral composition of 24 indigenous plants of Burkina Faso. Journal of food composition and analysis 10: 205-217.

Holland, B; Welch A.A, Unwin I.D, Buss D.H, Paul, A.A and Southgate D.A.T (1997). McCance and Widdowson's the composition of foods. Fifth revised and extended edition. The Royal Society of Chemistry and Ministry of Agriculture, Fisheries and Food, United Kingdom.p280-302.

Ihekoronye, A.I and Ngoddy P.O (1985). Integrated food science and technology for the tropics. Macmillan publishers London p366-367.

Kirk, R.S and Sawyer R (1991). Pearson's composition and analysis of foods. $9^{\text {th }}$ edition. Longman Scientific and Technical, United Kingdom.

Leakey, R.R.B (1999) Potential for novel food products from agroforestry trees: a review. Food Chemistry 66: 1-14.

Leger, S (2000-2003). http://www. sigridleger.de/book/plants/pl_106.html
Mateke, S.M (2001). Botswana's indigenous fruit tree domestication and improvement project 1997-2001, final report.

Murray, S.S; Schoeninger M.J, Bunn H.T, Pickering T.R and Marlett J.A. (2001). Nutritional composition of some wild plant foods and honey used by Hadza foragers of Tanzania. Journal of food composition and analysis 14:313

Odetokun, S M (1996). The nutritive value of Baobab fruit ( Andasonia digitata). La Rivista Italiana Delle Sostanze Grasse vol. LXXIII. Agosto. 371-373.

Saka, J.D. K; Msonthi J.D and Sambo E.Y. (1992). Dry matter, acidity and ascorbic acid contents of edible wild fruits growing in Malawi. Tropical science 32:217-221.

Saka, J.D. K and Msonthi J.D (1994). Nutritional value of edible fruits of indigenous wild trees in Malawi. Forest Ecology and management 64: $245-248$.

Smith, G.C; Clegg M.S, Keen C.L and Grivetti L.E (1996). Mineral values of selected plant foods common to southern Burkina Faso and to Niamey, Niger, West Africa. International Journal of Food Science and Nutrition 47: 4153. 